\title{
Penilaian Mata Pelajaran Bahasa Inggris
}

\author{
Mutiara O. Panjaitan \\ Pusat Kurikulum, Balitbang Kemdiknas
}

\begin{abstract}
Abstrak: Proses pembelajaran bahasa Inggris dikemas untuk mengembangkan kemampuan peserta didik menggunakan bahasa Inggri dalam kehidupan sehari-hari. Kegiatan pembelajaran dan penilaian merupakan proses terpadu, artinya penilaian dilakukan ketika kegiatan pembelajaran berlangsung. Berdasarkan kajian pada dokumen Kurikulum Tingkat Satuan Pendidikan (KTSP), bahwa pada umumnya kegiatan penilaian mata pelajaran Bahasa Inggris dirancang sebagai komponen lepas dari kegiatan pembelajaran dan terkesan formal. Di samping itu, kemampuan guru merancang tugas-tugas penilaian juga beragam yang berdampak pada kualitas hasil belajar peserta didik. Memperhatikan kondisi ini, dipandang perlu untuk mengembangkan model penilaian mata pelajaran Bahasa Inggris yang dapat dijadikan acuan bagi guru untuk mengembangkan kurikulum sekolah. Bahasa merupakan alat untuk berkomunikasi secara lisan dan tulis. Kompetensi berkomunikasi merupakan kemampuan seseorang untuk berkomunikasi baik secara lisan maupun tertulis dalam berkomunikasi. Untuk dapat berkomunikasi diperlukan seperangkat kompetensi lainnya: tindak bahasa, kebahasaan, pembentuk wacana, sosio kulural, dan strategi. Kompetensi-kompetensi tersebut merupakan satu kesatuan yang tidak dapat dipisahkan dan saling mendukung yang diwujudkan dalam keterampilan berbahasa, yaitu mendengarkan, berbicara, membaca, dan menulis.
\end{abstract}

Kata kunci: penilaian, kompetensi, berwacana, komunikatif, bahasa kurikulum, pembelajaran, dan teks

\begin{abstract}
The learning process of English subject is designed in line with the way English is used in society in everyday life. Teaching learning activity and assessment are integrated process. It means that assessment executed while learning activity is going on. Based on the investigation on school curriculum it is that learning activity and assessment were designed as separate components and in formal way. The task of assessment does not depict the real word. Besides, teachers' ability in designing assessment is various that will influence quality of output. Based on this situation it is needed to develop a model of assessment on English subject that could be used as a reference for teacher and stakeholders when developing school curriculum. Language is a tool for communication orally and written. Communication competence or discourse competence is a competence to communicate orally and written as well in certain communication event. Communicative competence needs a set of competencies i.e. actional competence, linguistic competence, discourse competence, sociocultural competence, and strategic competence. These competencies could not be separated and support each other which are realized through four language skills, i.e. listening, speaking, reading, and writing.Teachers are encourage to teach language using the four language skills in an integrated manner.
\end{abstract}

Key words: assessment, competence, discourse, coomunicative, language, curriculum, learning, and text 


\section{Pendahuluan}

Perubahan kurikulum yang terjadi sekarang ini sejalan dengan tuntutan masyarakat dan perkembangan global. Perubahan itu adalah dari kurikulum yang memberikan penekanan pada materi ke kurikulum berbasis kompetensi yang menekankan proses pembelajaran dalam rangka mencapai kompetensi yang ditargetkan. Dengan demikian, penyelenggaraan proses pembelajaran berorientasi pada penguasaan kompetensi sasaran oleh peserta didik sesuai dengan konteks lingkungannya, sehingga guru didorong untuk menerapkan prinsip-prinsip pembelajaran tuntas (mastery learning).

Undang Undang Republik Indonesia Nomor 20, Tahun 2003 tentang Sistem Pendidikan Nasional dan Peraturan Pemerintah Republik Indonesia Nomor 19, Tahun 2005 tentang Standar Nasional Pendidikan mengamanatkan bahwa penyusunan kurikulum merupakan tanggung jawab setiap satuan pendidikan (sekolah dan madrasah). Oleh karena itu, tidak lagi dikenal apa yang disebut dengan kurikulum nasional. Kurikulum yang dikembangkan oleh satuan pendidikan disebut dengan Kurikulum Tingkat Satuan Pendidikan (KTSP). Kurikulum pada semua jenjang dan jenis pendidikan dikembangkan mengacu pada Standar Nasional Pendidikan (SNP) yang memuat kompetensi bahan kajian dan kompetensi mata pelajaran yang harus dipenuhi oleh peserta didik pada jenjang dan jenis pendidikan tertentu. Pemerintah, dalam hal ini, Departemen Pendidikan Nasional hanya menentukan standar-standar minimal yang harus dipenuhi oleh satuan pendidikan. Standar minimal itu, di antaranya berupa Standar Kompetensi Lulusan, Standar Isi, Standar Proses, Standar Penilaian dan Standar Pengelolaan. Pengembangan lebih jauh terhadap standar-standar tersebut diserahkan pada daerah/satuan pendidikan masing-masing sesuai peraturan yang berlaku. Bagaimana standar-standar tersebut diterjemahkan menjadi kurikulum, diserahkan kepada satuan pendidikan bersangkutan. Sesuai Surat Edaran Menteri Pendidikan Nasional No. 33 tahun 2007 tentang Sosialisasi KTSP, maka masing-masing provinsi maupun kab/kota harus memiliki Tim Pengembang Kurikulum yang bertugas melakukan sosialisasi dan pelatihan sesuai dengan tingkatan masing-masing, sehingga daerah/satuan pendidikan terbantu dalam mengembangkan kurikulum sekolah.

Dalam implementasi kebijakan tersebut, hasil pengalaman penulis dalam melakukan bantuan teknis professional bagi Tim Pengembang Kurikulum (TPK) kabupaten/kota pada tahun 2008/2009 di beberapa provinsi menunjukkan bahwa belum semua satuan pendidikan mampu mengembangkan dan menyusun KTSP secara mandiri, khususnya Silabus dan Rencana Pelaksanaan Pembelajaran (RPP) mata pelajaran Bahasa Inggris. Mencermati kedua dokumen tersebut dapat diketahui bahwa masih banyak guru yang melakukan penilaian dengan cara lama, misalnya porsi penilaian unsur-unsur bahasa (language forms) masih lebih besar dari pada fungsi bahasa (language functions) yang seharusnya sama, tugas-tugas penilaian yang diberikan cenderung dalam konteks kelas yang seharusnya konteks dunia sehari-hari di mana bahasa target banyak digunakan, kegiatan pembelajaran dan penilaian cenderung terpisah sehingga penilaian dilakukan terkesan formal, kegiatan pembelajaran kurang menunjukkan keterpaduan keterampilanketerampilan berbahasa yang berdampak pula pada penilaian keterampilan bahasa yang juga berdiri sendiri. Kondisi lainnya, kemampuan guru sangat beragam di berbagai jenis dan jenjang sekolah, begitu juga di setiap daerah baik provinsi maupun kebupaten/kota. Keragaman kemampuan ini tentunya akan berdampak pada keragaman kualitas penyelenggaraan proses pembelajaran sehingga akan berdampak pula terhadap capaian belajar peserta didik.

Mengacu pada uraian di atas timbul pertanyaan, bagaimana cara menilai proses dan hasil pembelajaran bahasa Inggris, sehingga peserta didik terbantu mencapai kompetensi yang telah ditentukan pada standar isi? Pertanyaan tersebut dapat dirumuskan dengan kata lain seperti berikut ini, Bagaimanakah Model Penilaian Bahasa Inggris dalam KTSP?

Atas dasar permasalahan ini tampak perlu dikembangkan model penilaian Bahasa Inggris yang cocok dan sesuai dengan rambu-rambu yang ada pada Standar Isi guna membangun pemahaman pendidik, tenaga kependidikan, dan pihak-pihak yang terkait tentang makna penilaian 
serta mengembangkan kemampuannya dalam membuat dan melaksanakan penilaian dalam pembelajaran bahasa Inggris yang berorientasi pada penguasaan kompetensi, sesuai Kurikulum Berbasis Kompetensi. Tujuan dari pengembangan model penilaian ini adalah merupakan model alternatif pembelajaran bahasa Inggris. yang dapat dimanfaatkan oleh guru dan peserta didik pada satuan pendidikan dalam

\section{Kajian Literatur dan Pembahasan}

\section{Model Kompetensi}

Dalam Peraturan Menteri Pendidikan Nasional Indonesia Nomor 22, Tahun 2006 tentang Standar Isi untuk Satuan Pendidikan Dasar dan Menengah, ruang lingkup mata pelajaran Bahasa Inggris ada tiga. Pertama, kemampuan berwacana, yakni kemampuan memahami dan/atau menghasilkan teks lisan dan/atau tulis yang direalisasikan dalam empat keterampilan berbahasa yaitu mendengarkan, berbicara, membaca, dan menulis secara terpadu untuk mencapai tingkat literasi tertentu. Keempat keterampilan tersebut digunakan untuk menanggapi atau menciptakan wacana dalam kehidupan bermasyarakat. Oleh karena itu, mata pelajaran Bahasa Inggris diarahkan untuk mengembangkan keterampilanketerampilan tersebut agar lulusan mampu berkomunikasi dan berwacana dalam bahasa Inggris pada tingkat literasi tertentu. Kedua, kemampuan memahami dan menciptakan berbagai teks fungsional pendek dan monolog serta esei berbentuk ...(berbagai bentuk). Gradasi bahan ajar tampak dalam penggunaan kosa kata, tata bahasa, dan langkah-langkah retorika. Ketiga, kompetensi pendukung, yakni kompetensi linguistik, kompetensi sosiokultural, kompetensi strategi dan kompetensi pembentuk wacana.

Pengajaran bahasa untuk kemampuan berkomunikasi seperti tersebut di atas sejalan dengan model kompetensi komunikatif yang digagas para ahli bahasa selama ini, misalnya Celce-Murcia, Dornyei dan Thurrell. Menurut model ini, Kompetensi Wacana adalah kemampuan seseorang untuk berkomunikasi baik secara lisan maupun tertulis dalam sebuah peristiwa komunikasi. Bahasa yang dipilih dipengaruhi oleh topik yang dikomunikasikan, hubungan antarpribadi pihak yang terlibat dalam komunikasi , dan jalur komunikasi yang digunakan (lisan atau tulis). Ketiga faktor ini menentukan pemilihan berbahasa formal/informal, akrab/tidak akrab. Dengan demikian, peserta didik mampu berkomunikasi sesuai konteks yang dihadapinya (Celce-Murcia et al. 1995).

Dari uraian di atas dapat dikatakan bahwa teks dapat berupa tindakan lisan maupun tertulis. Hal ini sejalan dengan Standar Isi bahwa SK mata pelajaran Bahasa Inggris dirumuskan berdasarkan tindakan lisan (mendengarkan dan berbicara) dan tindakan tertulis (membaca dan menulis). Agar peserta didik mampu memahami dan mengungkapkan makna lisan maupun tertulis, yang disebut dengan istilah kompetensi tindak bahasa, diperlukan seperangkat kompetensi lain yaitu kompetensi kebahasaan, kompetensi pembentuk wacana, kompetensi sosio kulural, dan kompetensi strategis. Kelima kompetensi tersebut merupakan satu kesatuan yang utuh yang tidak terpisahkan dan saling mendukung yang diwujudkan dalam keempat keterampilan berbahasa sebagaimana diungkapkan CelceMurcia et al. (1995) sebagai berikut: 1) kompetensi tindak bahasa, yaitu kemampuan mengambil peran dalam komunikasi, yang disebut tindak tutur untuk lisan dan retorika untuk tulis. Ketika orang berbicara, ia berperan atau bertindak. Misalnya, bertindak "menyapa, meminta/memberi informasi, mengundang, menawarkan". Agar orang lain memahami maksud si pembicara, ia perlu memilih kosakata, tata bahasa, dll. untuk merealisasikannya. Kompetensi tindak bahasa meliputi keterampilan mendengarkan, berbicara, membaca, dan menulis; 2) kompetensi kebahasaan, yaitu kompetensi berkaitan dengan kemampuan menggunakan bunyi, kosakata, tata bahasa, intonasi, kalimat, dan sebagainya. Kompetensi ini merealisasikan kompetensi tindak bahasa; 3 ) kompetensi pembentuk wacana, yaitu kompetensi yang diperlukan untuk menyusun atau menafsirkan serangkaian kalimat atau ungkapan sehingga membentuk makna yang utuh, seperti penggunaan kata sambung, pengulangan kata, penggunaan kata ganti; 4) kompetensi sosiokultural, yaitu kompetensi terkait dengan pemilihan berbahasa yang dipengaruhi oleh pengetahuan sosial budaya si pembicara (pemilihan kata, gaya bahasa, sopan santun), 
hubungan interpersonal antara pengguna bahasa dalam konteks budaya dimana komunikasi berlangsung, apakah berbahasa formal/informal, akrab/tidak akrab, dan sebagainya; dan 5) kompetensi strategis (Strategic Competence), yaitu kompetensi yang diperlukan untuk mengatasi masalah-masalah yang timbul terutama dalam komunikasi lisan, seperti: mengulangi atau mengatakan dengan cara lain.

Sementara itu Bachman (1991) memberi istilah kompetensi komunikatif dengan istilah kecakapan berbahasa (language ability), yaitu sebagai suatu konstruk yang seharusnya diukur dalam tes berbahasa. Dengan demikian, pembelajaran harus diarahkan untuk penguasaan kompetensi keempat keterampilan berbahasa tersebut agar lulusan mampu berkomunikasi. Sebagai contoh, untuk keterampilan berbicara, pembelajaran diarahkan untuk mengembangkan kompetensi peserta didik melakukan tindak tutur seperti membuka percakapan, mempertahankannya, menutup percakapan, meminta tolong, menyapa, mengungkapkan kegembiraan, meminta maaf, mengundang dan sebagainya dalam konteks tertentu. Untuk keterampilan menulis, pembelajaran diarahkan untuk mengembangkan kemampuan peserta didik melakukan langkahlangkah komunikasi (retorika), seperti mengelaborasi, menambah, mempertajam gagasan, dan menyimpulkan.

Dengan pembelajaran berorientasi pada pengembangan keterampilan berbahasa, sistem penilaian dalam pembelajaran bahasa Inggris seharusnya juga menjadikan keterampilan berbahasa sebagai dasar berpijak untuk pengembangan penilaiannya. Dalam penilaian, yang penting ialah guru menilai penggunaan bahasa untuk melihat apakah kompetensi komunikatif yaitu kompetensi berkomunikasi sudah tercapai atau belum.

\section{Makna dan Fungsi Penilaian}

Penilaian dalam mata pelajaran bahasa Inggris adalah suatu kegiatan untuk mengukur penguasaan bahasa Inggris peserta didik, agar diperoleh informasi sejauh mana indikatorindikator keberhasilan yang telah dirumuskan telah menampak pada perilaku berbahasa Inggris peserta didik. Hasil penilaian dapat di- komunikasikan kepada peserta didik secara kualitatif, dalam bentuk deskripsi tentang perilaku berbahasanya, ataupun secara kuantitatif, dalam bentuk nilai, atau keduanya. Apapun bentuknya, penilaian merupakan bagian yang tidak terpisahkan dari kegiatan pembelajaran dan harus dapat memberikan dampak yang positif terhadap pengembangan kompetensi sasaran. Dengan demikian, penilaian dilakukan sepanjang proses pembelajaran berlangsung.

Selama ini banyak guru menganggap bahwa penilaian adalah sama dengan atau merupakan persamaan kata dari tes atau ujian, yang pelaksanaannya adalah setelah selesai proses pembelajaran. Tujuannya tidak lain untuk memberikan 'nilai'. Mengacu pada uraian makna penilaian tersebut di atas, tentunya pandangan ini kurang tepat dan perlu diluruskan.

Ada beberapa alasan mengapa guru perlu menilai peserta didiknya. Popham (1995) mengajukan beberapa alasan, diantaranya adalah (1) untuk mendiagnosis keberhasilan dan kelemahan peserta didik, (2) memonitor perkembangan peserta didik dalam mempelajari suatu kompetensi. Dalam hal belajar bahasa Inggris, Informasi dapat diperoleh melalui hal-hal yang dihasilkan atau dilakukan oleh peserta didik. Untuk itu, guru perlu secara terus menerus melakukan observasi atau mengamati perilaku peserta didik, memberi penugasan baik perorangan, berpasangan, maupun kelompok, mempertimbangkan baik hasil penilaian diri peserta didik maupun hasil penilaian teman. Dengan begitu, guru dan peserta didik dapat mengetahui tingkat penguasaan bahasa Inggris dan kekuatan serta permasalahan yang dihadapi dalam belajar melalui hal-hal yang dihasilkan atau dilakukan peserta didik.

Dari cara pelaksanaannya, kegiatan penilaian dapat dilaksanakan secara informal ataupun secara formal. Penilaian informal dilaksanakan selama proses pembelajaran, dari sekadar komentar, pertanyaan atau jawaban spontan dan tidak direncanakan, sampai dengan pemberian feedback terhadap latihan dan portofolio peserta didik. Penilaian ini dapat dilakukan guru, teman, atau diri sendiri. Penilaian informal menjadi bagian yang tidak terpisahkan dari kegiatan pembelajaran, sehingga penilaian berjalan bersamasama dengan proses pembelajaran. 
Penilaian formal biasanya dirancang secara khusus untuk mengukur penguasaan unsur-unsur kompetensi tertentu yang telah ditetapkan sebelumnya dan juga dilaksanakan dalam waktu dan jangka waktu tertentu. Teknik yang paling lazim digunakan adalah tes dan ujian.

Dilihat dari fungsinya, penilaian dapat dikelompokkan ke dalam penilaian formatif dan penilaian sumatif. Sebagian besar kegiatan penilaian yang dilaksanakan guru adalah penilaian formatif, karena dilaksanakan selama proses pembentukan (forming) kompetensi sasaran, yang tujuannya adalah untuk membantu peserta didik mengembangkan kompetensi tersebut. Penilaian formatif berorientasi pada proses dengan tujuan memberikan balikan secara terus menerus agar kualitas proses dapat ditingkatkan. Baik guru maupun peserta didik dapat memperbaiki kekurangannya selama proses berlangsung. Oleh karena itu, semua bentuk penilaian informal dapat dianggap sebagai penilaian formatif. Dalam konteks pengajaran bahasa Inggris penilaian formatif sangatlah penting. Semakin dini kelemahan anak diketahui semakin baik, karena dapat segera diatasi melalui umpan balik yang diberikan guru. Shohamy dalam Kern (2000:273) menyarankan agar guru banyak menggunakan observasi, wawancara, portofolio untuk memperoleh gambaran yang lebih lengkap tentang kemampuan berbahasa peserta didik.

Adapun penilaian sumatif bertujuan terutama untuk mengukur atau lebih tepatnya mendapatkan informasi tentang pencapaian peserta didik pada akhir periode program pengajaran. Quiz, ujian tengah semester, dan ujian akhir semester adalah beberapa contoh tes sumatif.

\section{Prinsip-prinsip Penilaian Bahasa}

Penilaian apa pun yang digunakan, Kern (2000: 16-17) menyarankan 7 prinsip hendaknya guru pertimbangkan ketika merancang butir-butir soal dan tugas-tugas penilaian, yaitu: 1) Interpretasi, penulis dan pembaca menginterpretasi realita yang dihadapi, seperti peristiwa, pengalaman, gagasan, dan kemudian "menerjemahkan" realita tersebut ke dalam bahasa. Penulis menginterpretasikan realita ke dalam tulisannya. Pembaca menginterpretasikan tulisan yang dibaca berdasarkan pemahamannya sendiri tentang realita. Karena itu, berikan tugas-tugas penilaian yang menuntut peserta didik melakukan interpretasi terhadap apa yang dibaca maupun yang didengarnya. Misalnya, bagian akhir suatu teks dihilangkan, kemudian anak ditugaskan untuk menyelesaikan teks tersebut sesuai interpretasinya. Atau, anak diminta menceritakan kejadian dalam teks dari sudut pandang orang lain; 2) Kolaborasi, ketika seseorang berbicara atau menulis, ia perlu mempertimbangkan siapa yang diajak berkomunikasi. Sebagai pembaca, ia berusaha memahami maksud penulis dengan mengerahkan segala pengetahuan dan pengalaman yang dimilikinya, sehingga teks yang dibaca bermakna. Dalam penilaian formatif, proses ini sangat penting; 3) Konvensi, cara orang membaca dan menulis dikendalikan oleh kaidah dan kebiasaan yang ada pada budayanya. Membaca teks dalam bahasa asing perlu menyesuaikan diri dengan konvensi yang tidak biasa ditemukan dalam bahasa asli pembaca. Misalnya, struktur teks bahasa Indonesia tidak sama dengan struktur teks bahasa Inggris. Ketepatan tanda baca, tata bahasa, susunan teks, merupakan indikator penting dalam kemampuan menulis; 4) Pengetahuan budaya, keempat keterampilan berbahasa berfungsi dalam satu sistem sikap, keyakinan, kebiasaan, cita-cita, dan nilai-nilai tertentu. Ketika anak mencoba berbahasa Inggris dengan masih menggunakan sistem budaya Indonesia, ia beresiko mengalami kesalahfahaman atau disalahfahami oleh pihak yang tidak mengerti latar budaya anak. Dalam penilaian, tugas-tugas seharusnya menjangkau aspek ini; 5) Pemecahan masalah, pada dasarnya orang berkomunikasi untuk memecahkan masalah. Dalam membaca anak terlibat dalam menafsirkan makna kata berdasarkan konteks yang melingkupinya. Ia juga didorong untuk menemukan hubungan makna teks dengan dunia yang dibayangkan. Dalam penilaian hendaknya peserta didik dihadapkan pada tantangan komunikasi yang merupakan rangkaian penyelesaian masalah. Misalnya, menulis undangan untuk suatu acara kepada berbagai pihak. Tentu undangan yang ditulis berbeda, disesuaikan dengan siapa yang diundang. Melakukan percakapan yang sebenarnya, menjelaskan apa yang dibaca anak; 6) Refleksi, kegiatan berbahasa tidak hanya memahami atau mengungkapkan 
gagasan yang sedang dikomunikasikan, tetapi juga memberi kesempatan untuk refleksi mengenai perilaku berbahasa. Misalnya, refleksi bagaimana teks disusun, bagaimana gagasan ditata dan dihubungkan. Dalam proses menulis peserta didik perlu menjelaskan langkah dan alasan mengapa menulis seperti itu; dan 7) Penggunaan bahasa, Literasi memerlukan pengetahuan bahasa dalam konteks lisan dan tulis untuk menciptakan wacana. Artinya, anak mampu membicarakan, menulis, memahami, atau membaca hal-hal yang bersangkutan dengan hidupnya. Dalam penilaian, guru memberikan tugas-tugas untuk menilai penggunaan bahasa, apakah kompetensi berwacana atau berkomunikasi sudah tercapai atau belum.

\section{Kriteria Penilaian}

Ada beberapa kriteria yang perlu digunakan ketika merancang penilaian, sehingga hasilnya baik dan efektif. Gronlund (1982: 47-81) dan Bachman (1991:160-161) menyatakan bahwa validitas dan reliabilitas merupakan dua hal esensial yang menentukan keefektifan suatu tes. Keduanya diperlukan untuk memenuhi dua kondisi berikut, yaitu: 1) meminimalkan efek kesalahan pengukuran; dan 2) memaksimalkan efek kemampuan berbahasa yang ingin kita ukur. Sedangkan Brown (2004:19) menambahkan tiga hal, di samping validitas dan reliabilitas, yaitu praktis, autentik, dan washback.

\section{Validitas}

Validitas berkaitan dengan sejauh mana hasil penilaian dapat digunakan untuk tujuan yang dikehendaki. Validitas berkaitan dengan kelayakan, kebermaknaan, dan kegunaan yang disimpulkan dari hasil penilaian bagi tujuan tertentu (Linn dan Gronlund,1995:47). Investigasi validitas berkenaan dengan pertanyaan,'Sejauh mana hasil tes seseorang terkait dengan kemampuan berbahasa yang akan diukur?' dengan cara memaksimalkan efek kemampuan berbahasa tersebut terhadap skor tes (Bachman,1991:161).

Penilaian dikatakan valid, misalnya jika ingin menilai kemampuan membaca pemahaman peserta didik maka interpretasi harus berdasarkan bukti yang merefleksikan kemampuan membaca pemahaman; jika ingin menilai kemampuan peserta didik berbicara tentang hobinya dalam bahasa Inggris maka dilakukan wawancara.

Validitas tidak berlaku secara umum tetapi berlaku bagi kelompok tertentu dan tujuan tertentu. Suatu penilaian dikatakan valid untuk menilai kemampuan membaca pemahaman bahasa Inggris, tetapi tidak valid untuk menilai kemampuan mengeja. Atau, suatu penilaian dikatakan valid untuk mengukur kemampuan peserta didik SMA membaca teks bahasa Inggris, tetapi tidak valid untuk menilai kemampuan membaca bahasa Inggris untuk tingkat SMP.

Validitas isi (content validity) digunakan untuk penilaian hasil belajar (achievement test). Validitas isi sering juga disebut validitas kurikuler karena penilaian disusun bersumber dari kurikulum mata pelajaran yang hendak dinilai. Bentuk penilaian semacam ini ingin menilai sejauhmana seseorang menguasai suatu kemampuan sesuai tuntutan kurikulum (Gay, 1987:129).

Untuk mengetahui validitas isi suatu tes hasil belajar dapat dilakukan dengan cara membandingkan butir-butir soal dengan kompetensi yang telah ditentukan untuk mata pelajaran yang bersangkutan. Apakah kompetensi yang dikehendaki telah tercermin dalam butir-butir tes itu dan terwakili secara nyata. Jika hasil analisis menunjukkan bahwa butir-butir tes telah menerjemahkan kompetensi yang dikehendaki maka penilaian tersebut telah memiliki validitas isi. Apabila pada kurikulum dituntut kompetensi membaca: menentukan gagasan utama, mendapatkan informasi faktual, menentukan gagasan pendukung, Butir-butir soal yang dirancang harus menilai performansi keterampilan tersebut.

\section{Reliabilitas}

Reliabilitas berkaitan dengan konsistensi atau keajegan hasil penilaian. Konsistensi memungkinkan suatu penilaian valid (Linn dan Gronlund, 1995). Investigasi reliabilitas berkaitan dengan jawaban atas pertanyaan, 'Sejauh mana hasil tes seseorang disebabkan kesalahan pengukuran atau faktor-faktor selain kemampuan berbahasa yang akan diukur? akan dilakukan dengan meminimalkan efek faktor-faktor tersebut terhadap skor tes (Bachman, 1991: 160-161). 
Semakin banyak tugas-tugas penilaian, semakin tinggi tingkat reliabilitasnya (Linn dan Gronlund, 1995: 99).

Ada beberapa faktor yang bisa membuat hasil penilaian tidak reliabel di antaranya: 1) Ketika penilaian dilakukan peserta didik dalam keadaan tidak sehat, cemas, lelah, atau tidak bersemangat; 2) Pemberian nilai tidak ajeg, karena para penilai tidak menggunakan kriteria yang sama, atau penilai dalam keadaan lelah sehingga agak ceroboh; 3) Lembar soal kurang jelas terbaca, atau suara tidak jelas terdengar oleh peserta didik ketika digunakan menilai kemampuan mendengarkan; 4) Tes terlalu panjang atau memakan waktu terlalu lama sehingga penilai merasa lelah dan penyekoran menjadi kurang tepat.

Dari uraian di atas dapat dinyatakan bahwa keajegan hasil penilaian sebagian ditentukan oleh faktor fisik dan penilai (rater). Karena itu, ketika melaksanakan penilaian, khususnya penilaian formal, perlu memperhatikan ha-hal berikut: 1) setiap peserta didik mendapatkan lembar fotokopi tes yang bersih dan jelas; 2) untuk tes lisan kualitas rekaman harus baik sehingga suara jelas terdengar bagi semua peserta didik; 3) apabila menggunakan video, gambar harus jelas terlihat; 4) pencahayaan, temperatur, suara, dan kondisi kelas tidak mengganggu peserta didik; 5) prosedur penyekoran objektif; 6) khusus soal uraian (jawaban terbuka), penilai atau rater: (a) menggunakan kriteria yang konsisten, (b) memberi perhatian yang sama pada semua jawaban, (c) membaca soal paling sedikit dua kali agar penyekoran ajeg, (d) membaca butir soal yang sama untuk semua peserta didik, setelah butir tersebut selesai diperiksa baru pindah ke butir selanjutnya, (e) menggunakan standar yang sama bagi semua jawaban.

\section{Autentik}

Autentik berkaitan dengan kesesuaian tugas penilaian bahasa dengan situasi komunikasi yang sesungguhnya atau dunia nyata (Bachman, 1991:301). Penilaian autentik, di antaranya penulisan esai, laporan, desain proposal, portofolio (McNamara, 1996:13).

Menurut Brown (2004:28), penilaian dikatakan autentik apabila mencerminkan 8 hal berikut, yaitu: 1) bahasa yang digunakan pada soal-soal alami atau wajar; 2) butir-butir tes kontekstual tidak berdiri sendiri (isolated); 3) Topik yang ditawarkan bermakna (relevan, menarik) bagi peserta didik; 4) Rangkaian soal-soal membentuk cerita atau episoe; 5) Tugas-tugas penilaian menggambarkan, paling tidak mendekati tugas-tugas dalam kehidupan nyata; 6) Teks yang digunakan untuk kemampuan membaca dipilih dari majalah, surat kabar atau sumber lainnya; 7) Kemampuan produktif dinilai melalui performansi peserta didik. Kemampuan mendengarkan dinilai melalui mendengarkan pemahaman yang dilengkapi dengan hesitations, white noise, dan interruptions; 8) Teks-teks yang digunakan untuk menilai dapat berupa kalimat, topik atau cerita.

\section{Praktis}

Suatu penilaian dikatakan praktis apabila: 1) biaya untuk melaksanakan terjangkau; 2) pelaksanaannya tidak terlalu lama, sehingga tes mampu diselesaikan sesuai waktu yang telah ditetapkan; 3) pengadministrasiannya jelas dan mudah dilakukan; 4) penyekoran dan penginterpretasian tidak memakan waktu lama. Hasilnya mudah ditafsirkan.

\section{Washback}

Washback adalah pengaruh tes terhadap proses belajar mengajar (Brown: 2004, p. 28). Untuk menilai kemampuan berbicara tentang identitas tentu dengan melakukan wawancara atau bermain peran, sehingga dalam pembelajaran peserta didik banyak dilatih berbicara mengungkapkan identitasnya. Penilaian yang mengandalkan soal-soal bentuk pilihan ganda yang menguji pengetahuan dan pemahaman peserta didik, akan berpengaruh pada pembelajaran. Selama proses pembelajaran peserta didik akan banyak dilatih menjawab pertanyaan-pertanyaan untuk pengetahuan dan pemahaman.

Bentuk washback positif yang sering terjadi di dalam kelas adalah informasi balikan tentang kekuatan dan kelemahan peserta didik dalam bentuk setelah penilaian dilakukan. Penilaian informal lebih memiliki efek washback daripada penilaian formal, karena guru biasanya memberikan catatan sebagai umpan balik bagi 
peserta didik setelah penilaian informal berlangsung. Sebaliknya, dengan penilaian formal, guru hanya memberikan skor perolehan peserta didik (Brown: 2004,p.29).

Salah satu cara untuk meningkatkan efek washback pada pembelajaran yaitu mengembalikan kertas tugas penilaian peserta didik beserta catatan-catatan sebagai umpan balik bagi peserta didik. Beri pujian untuk hasil yang baik, atau beri komentar yang membangun bila hasilnya kurang baik.

Kelima prinsip penilaian tersebut sama pentingnya, tergantung konteksnya. Bagi tes standar berskala besar prinsip kepraktisan lebih penting daripada washback, sebaliknya washback lebih penting bagi penilaian informal daripada kepraktisan. Namun, dari kelima prinsip di atas validitas merupakan yang terpenting dalam merancang penilaian. Tulisan ini banyak membahas pelaksanaan penilaian formatif atau informal, karena itu prinsip validitas, autentik, dan washback lebih banyak berperan ketika melaksanakan penilaian.

\section{Model Penilaian Bahasa Inggris}

Berbagai cara dapat dilakukan untuk mengumpulkan informasi tentang kemajuan belajar peserta didik, baik yang berhubungan dengan proses belajar maupun hasil belajar. Cara yang digunakan tentunya berdasarkan kompetensi yang harus dicapai peserta didik. Dalam Standar Isi mata pelajaran bahasa Inggris, standar kompetensi (SK) dan kompetensi dasar (KD) dikelompokkan ke dalam empat keterampilan bahasa, yaitu mendengarkan, berbicara, membaca, dan menulis (Depdiknas, 2004a). Namun, dalam kegiatan pembelajaran, keterampilan berbahasa tersebut hendaknya terpadu, boleh mengintegrasikan dua keterampilan atau lebih. Perlu diingat bahwa keterpaduan keterampilan-keterampilan berbahasa sangat penting dalam pembelajaran bahasa.

Perumusan SK dan KD pada kompetensi mendengarkan sama dengan pada berbicara. Yang membedakannya adalah pada mendengarkan menggunakan kata kerja memahami makna, sedangkan pada berbicara menggunakan kata kerja mengungkapkan makna. Karena itu, dalam kegiatan pembelajaran hendaknya pengembangan kompetensi mendengarkan dan berbicara dilakukan secara terpadu. Demikian halnya dalam penilaian, tugas-tugas yang diberikan adalah untuk menilai kompetensi mendengarkan dan berbicara. Namun, diperlukan juga menilai kompetensi mendengarkan dan berbicara sebagai bagian yang terpisahkan, sesuai dengan kompetensi yang dituntut. Kompetensi-kompetensi pen-dukung merupakan bagian dari kriteria atau aspek yang perlu diamati dan dinilai ketika menilai keterampilan berbahasa Depdiknas, 2004b).

Berikut contoh-contoh tugas penilaian bahasa Inggris yang juga menjadi kegiatan pembelajaran, sehingga penilaian dilakukan ketika kegiatan pembelajaran berlangsung. Namun, tugas-tugas ini juga dapat digunakan untuk penilaian sumatif yang tujuannya untuk mengakumulasikan nilai hasil belajar.

\section{Mendengarkan dengan Berbicara}

Ketika memasuki kelas, guru sudah membawa format pengamatan yang memuat nama-nama siswa beserta aspek-aspek yang akan diamati, seperti: penggunaan kosa kata, tata bahasa, intonasi, dan lafal secara benar dan lancar. Berikut contoh-contoh tugas untuk menilai keterampilan berbahasa lisan atau kemampuan mendengarkan dan berbicara yang dilakukan dengan terpadu.

\section{Bercakap-cakap dan bertanya jawab}

Kemampuan bercakap-cakap dan bertanya jawab dalam bahasa Inggris dapat dinilai dengan menggunakan berbagai stimuli, misalnya gambar, situasi, peta. Kegiatan dapat dilakukan dengan cara 'role-play' atau berdasarkan 'model' pembicaraan yang disediakan oleh guru. Untuk peserta didik SMP yang kemampuan berbahasa Inggrisnya masih sangat rendah dan terbatas, tidak ada salahnya model pembicaraan atau petunjuk role-play diberikan dalam bahasa Indonesia. Dengan bahasa Inggris ada kemungkinan peserta didik lebih sulit memahami model pembicaraan atau petunjuk role-play daripada mengerjakan tugas itu sendiri. Keuntungan menggunakan stimuli dalam bahasa Indonesia adalah dapat dihindari kemungkinan peserta didik mengulang secara mekanis kata-kata yang terdapat di dalam model yang dapat diterapkan di dalam pembicaraan. 
Berikut ini contoh menilai kemampuan bertanya jawab tentang data diri. Untuk mengerjakan tugas tersebut, peserta didik perlu mempelajari petunjuk role-play yang diberikan guru dengan seksama.

Contoh petunjuk role play

Peserta didik 1: Menanyakan umur salah satu peserta didik yang diketahui Peserta didik 2 dengan baik di kelas.

Peserta didik 2: Menjawab, jika tidak tahu katakan tidak tahu, dan jika tahu katakan berapa umurnya.

Peserta didik 1: Menanyakan apakah peserta didik tersebut punya adik atau kakak.

Peserta didik 2: Mengatakan tidak kalau tidak punya; menyebutkan berapa kakak-adiknya dan namanya masing-masing.

Peserta didik 1: Menanyakan tempat tinggal peserta didik yang dimaksud.

Peserta didik 2: Menyebutkan tempat tinggalnya.

Dengan model yang sama, peserta didik ke 2 berganti peran sebagai penanya dan peserta didik ke1 sebagai penjawab. Untuk menghemat waktu peserta didik bekerja berpasangan. Ketika peserta didik melakukan tugas, guru hendaknya berkeliling mendengarkan dan mengamati dengan menggunakan format pengamatan sambil membuat catatan-catatan. Karena keterbatasan waktu, sebaiknya guru fokus pada beberapa pasangan dalam kesamaan waktu. Pada kesempatan yang lain guru fokus pada pasangan lain yang belum teramati. Begitu seterusnya hingga semua peserta didik dalam satu kelas teramati. Berikut contoh format pengamatan untuk menilai keterampilan mendengarkan/ berbicara.

Cara ini bisa digunakan untuk penilaian sumatif yang tujuannya untuk merangkum hasil belajar pada periode tertentu atau pada akhir program. Setiap kelompok atau pasangan memperagakan kemampuannya di depan guru, sedangkan kelompok atau pasangan lain menunggu di luar ruangan. Guru dapat langsung memberikan penilaiannya dan/atau merekam kegiatan peserta didik dengan menggunakan audio-recorder. Dengan menggunakan rekaman guru dapat memberikan penilaian yang lebih teliti. Bila guru ingin memberi penilaian langsung, dapat menggunakan format pengamatan yang berisi perilaku-perilaku yang akan diamati dan memberi skor berdasarkan kriteria penilaian, seperti contoh format pengamatan pada Tabel 1 .

\section{Retelling}

Retelling adalah tugas untuk menilai kemampuan menceritakan kembali secara lisan atau tertulis dengan bahasa sendiri suatu teks yang diperdengarkan. Dalam hal ini peserta didik harus mampu mengidentifikasi intisari teks, gagasan pokoknya, tujuannya, gagasan pendukung, atau kesimpulan yang menunjukkan bahwa ia memahami keseluruhan teks. Apabila dilakukan secara lisan, untuk mencatat hasil penilaian dapat menggunakan format pengamatan yang digunakan untuk bercakap-cakap, dengan menambahkan aspek kelengkapan gagasan.

Seandainya tidak memiliki alat audio untuk memperdengarkan suatu teks, guru dapat melaksanakannya dengan membacakan teks yang dimaksud. Cara ini bisa memperoleh hasil yang

Tabel 1. Contoh format pengamatan

\begin{tabular}{|l|l|l|l|l|l|l|l|}
\hline \multirow{2}{*}{ Nama } & \multicolumn{6}{|c|}{ Aspek } \\
\cline { 2 - 8 } & ucapan & $\begin{array}{l}\text { Tata } \\
\text { bahasa }\end{array}$ & $\begin{array}{l}\text { Kosa } \\
\text { kata }\end{array}$ & $\begin{array}{l}\text { Kelancar- } \\
\text { an }\end{array}$ & $\begin{array}{l}\text { Pemaham- } \\
\text { an }\end{array}$ & $\begin{array}{l}\text { Kesesuaian } \\
\text { bahasa }\end{array}$ & strategi \\
\hline Rona & & & & & & & \\
\hline Okta & & & & & & & \\
\hline Etc. & & & & & & & \\
\hline
\end{tabular}

Catatan:

1) Kesesuaian bahasa berkaitan dengan sejauh mana bahasa yang digunakan sesuai dengan konteks komunikasi dan sosial budaya.

2) Strategi berkaitan dengan usaha peserta didik mengatasi permasalahan yang timbul ketika berkomunikasi berlangsung. 
optimal bila guru memperhatikan hal-hal berikut ketika membacakan teks, yaitu: 1) Usahakan agar nada bicara terkesan berbicara langsung dengan peserta didik dan bukan membaca. Gunakan ekspresi atau ungkapan yang normal dipakai dalam bahasa lisan; 2) Hindari menggunakan teks yang terlalu panjang; 3) Jangan menghafal teks, karena akan membuat cara anda menyampaikan menjadi tidak wajar; dan 4) Gunakan jeda yang agak lama di antara klausa dan kalimat. Ini lebih baik dan wajar dibanding membaca kalimat secara pelan-pelan.

\section{Mendengarkan dengan Menulis}

Note-taking, yaitu membuat catatan dari suatu ceramah pendek

\section{Information transfer:}

Tugas ini menghendaki peserta didik mengisi tabel dengan data sesuai informasi yang diperdengarkan sebagaimana tampak pada Tabel 2.

Instruksi: Listen to the information about Lucy's schedule. Remember, you will first hear all the sentences; then you will hear each sentence separately with time to fill in your chart.

Lucy gets up at 8:00 every morning except on weekends. She has English on Monday, Wednesday, and Friday at ten o'clock. She has History on Tuesdays and Thursdays at two o'clock. She takes Chemistry on Monday from two o'clock to six o'clock. She plays tennis on weekends at four o'clock. She eats lunch at twelve o'clock every day except Saturday and Sunday

\section{Mendengarkan dengan Berbicara dan Menulis}

Peserta didik misalnya menonton film yang mereka tentukan sendiri, kemudian menceritakan kembali isi film yang ditonton tersebut kepada temantemannya di kelas, tugas diakhiri dengan membuat sinopsis film tersebut secara tertulis.

\section{Membaca dengan Menulis dan Berbicara}

Peserta didik menceritakan isi puisi yang dibaca lalu mengubah bentuk puisi ke dalam bentuk prosa.

\section{Mendengarkan}

Mendengarkan untuk memahami pembicaraan, seperti: listening for the gist, for the main idea, and making inferences.

\section{Berbicara}

Melakukan monologue, yaitu kemampuan menghasilkan teks lisan, seperti: speeches, oral presentations, story- telling, Retelling a story, and News Event. Tugas monologue disesuaikan dengan bentuk teks yang dikehendaki pada kompetensi dasar, misalnya naratif, report, recount.

\section{Membaca}

\section{Membaca untuk Memahami Langkah-Langkah Retorika}

Perlihatkanlah teks bentuk tertentu kepada peserta didik. Lalu minta mereka mengidentifikasi bagian-bagian teks tersebut menurut struktur teksnya (Generic Structure) dan ciri-ciri kebahasaannya (Language Features)

Tabel 2. Contoh Tabel aktifitas yang harus diisi

\begin{tabular}{|l|l|l|l|l|l|l|}
\hline Time & Monday & Tuesday & Wednesday & Thursday & Friday & Weekends \\
\hline $08: 00$ & get up & get up & get up & get up & get up & \\
\hline $10: 00$ & English & & English & & English & \\
\hline $12: 00$ & lunch & lunch & lunch & lunch & lunch & \\
\hline $2: 00$ & Chemistry & History & & History & & \\
\hline $4: 00$ & Chemistry & & & & & tennis \\
\hline $6: 00$ & Chemistry & & & & & \\
\hline
\end{tabular}


Contoh:

Jenis Teks: Report (Laporan Pengamatan)

Language Features: focus on Generic Participants (groups of things)

\begin{tabular}{|l|l|}
\hline Dolphins & $\begin{array}{l}\text { general } \\
\text { Dolphins are sea mammals. They have to breathe air or they will } \\
\text { classification } \\
\text { die. They are members of the corphaenidae Family. }\end{array}$ \\
$\begin{array}{l}\text { Dolphins hunt together in a group. A group of dolphins is called a } \\
\text { pod. They eat fish, schrimp and small squid. They live in salt water } \\
\text { oceans. Dolphins can hold their breath for six minutes. }\end{array}$ \\
$\begin{array}{l}\text { Dolphins have smooth bare skin. Only baby dolphins are born with } \\
\text { a few bristly hairs on their snouts. These hairs soon fall out. They } \\
\text { have a long tail and the fin on top of their backs keeps the dolphins } \\
\text { from rolling over. The female dolphins have a thick layer of fat } \\
\text { under their skin to keep them warm when they dive very deep. The } \\
\text { dolphins front fins are called flippers. They use them to turn left } \\
\text { and right. Dolphins grow from } 2 \text { to } 3 \text { metres long and weigh up to } \\
\text { 75 kilograms. }\end{array}$ & description \\
\hline $\begin{array}{l}\text { When dolphins hear or see ship close by, they go near it and follow } \\
\text { it for many kilometers. Dolphins can leap out of the water and so } \\
\text { somersaults. Sometimes they invent their own tricks and stunts } \\
\text { after watching other dolphins perform. }\end{array}$ & \\
\hline $\begin{array}{l}\text { Dolphins are very friendly to people and have never harmed } \\
\text { anyone. They are very playful mammals. }\end{array}$ & \\
\hline
\end{tabular}

Sumber: Callaghan et al. 1988.Teaching Factual Writing, hal. 61

\section{Membaca Nyaring}

Data kemampuan membaca nyaring dapat juga menjadi bagian dari data penilaian kemampuan berbicara anak. Sebelum peserta didik membacakan teks, siapkan format pengamatan seperti pada tabel 4 berikut. Ketika peserta didik membaca amati hal-hal yang berkaitan dengan aspek yang akan dinilai kemudian beri tanda pada kemampuan yang teramati. Untuk melihat perkembangan anak isilah tanggal pada waktu pengamatan dilakukan.

\section{Menulis}

\section{Proses Menulis}

Menulis dipandang sebagai suatu proses yang meliputi prewriting, drafting, revising, editing dan hasil terbaik. Guru memberi contoh teks, peserta didik mencoba membuat sendiri, mendiskusikan tulisan dengan guru, memperbaiki tulisannya, mengedit tulisan sampai mendapatkan hasil terbaik. Dalam diskusi guru dan peserta didik membahas hal-hal yang sudah dan belum dikuasai peserta didik. Misalnya, penggunaan tata bahasa, struktur teks, pengembangan atau kejelasan gagasan, keterkaitan gagasan yang satu dengan yang lain. Catatan guru beserta tulisan peserta

Tabel 4. Contoh Format Penilaian Membaca Nyaring

Nama: Okta

\begin{tabular}{|l|c|c|c|c|c|}
\hline \multirow{2}{*}{ Aspek } & \multicolumn{5}{c|}{ Tanggal } \\
\cline { 2 - 6 } & 05 Jan & 12 Feb & 03 Mar & $08 \mathrm{Apr}$ & 10 Mei \\
\hline Kelancaran Membaca & $\mathrm{k}$ & $\mathrm{c}$ & $\mathrm{k}$ & $\mathrm{b}$ & $\mathrm{b}$ \\
\hline Ketepatan Pengucapan & $\mathrm{k}$ & $\mathrm{c}$ & $\mathrm{c}$ & $\mathrm{b}$ & $\mathrm{b}$ \\
\hline Intonasi & $\mathrm{k}$ & $\mathrm{c}$ & $\mathrm{c}$ & $\mathrm{c}$ & $\mathrm{b}$ \\
\hline Tekanan kata & $\mathrm{c}$ & $\mathrm{k}$ & $\mathrm{c}$ & $\mathrm{c}$ & $\mathrm{b}$ \\
\hline Komentar guru: & & & & & \\
\hline
\end{tabular}

kode : $\mathrm{k}=$ kurang ; $\mathrm{c}=$ cukup ; $\mathrm{b}=$ baik 
didik dapat dikumpulkan pada map (folder) peserta didik, selanjutnya peserta didik diberi kesempatan memperbaiki tulisannya berdasarkan tanggapan guru tersebut. Kumpulan tulisan peserta didik ini membentuk portofolio. Pada akhir waktu yang telah ditetapkan diharapkan tulisan peserta didik sudah baik dan guru dapat mengambil nilai karya peserta didik tersebut.

\section{Menilai Tulisan}

Menilai tulisan harus berdasarkan kriteria yang sejak awal sudah ditetapkan dan dikomunikasikan kepada peserta didik, misalnya penggunaan: tata bahasa, piranti pembentuk wacana, langkahlangkah retorika, kejelasan gagasan. Gaudiani (dikutip Kern, 2000) menyarankan menilai tulisan dimulai dari hal-hal umum ke khusus, seperti: 1) Mulailah dari hal-hal yang bersifat global. Mengenai apakah tulisan itu, apa yang dicoba dibahas, apakah dapat dimengerti, apakah menarik, apakah gagasannya masuk akal, 2) Selanjutnya yang berkaitan dengan organisasi teks. Apakah pemaparan gagasan mudah diikuti atau pembaca dituntut berpikir keras, apakah penyajian gagasan ditata dengan logis, 3) Terakhir yang berkaitan dengan diction dan grammar, khususnya yang berkaitan dengan hal-hal yang membuat makna menjadi tidak jelas.

\section{Sikap}

Sikap ini merupakan bentuk reaksi positif peserta didik terhadap bahasa Inggris. Jadi penilaiannya tidak dapat berdiri sendiri tetapi terintegrasi pada semua keterampilan bahasa. Penilaian sikap, misalnya: Berinisiatif untuk berlatih dengan temannya dengan saling membacakan teks, menjawab/menanggapi pernyataan/pertanyaan dalam bahasa Inggris ketika berinteraksi dengan guru atau teman tanpa takut membuat kesalahan, Menunjukkan keterlibatan aktif dalam kegiatan ekstra barbahasa Inggris, Berpartisipasi aktif dalam kegiatan membahas setiap teks atau tugas dengan guru dan teman, Menyelesaikan setiap tugas yang diberikan.

\section{Simpulan dan Saran}

\section{Simpulan}

Pelimpahan wewenang kepada daerah dan satuan pendidikan dalam mengembangkan kurikulum diikuti dengan pembentukan TPK di tingkat provinsi dan kabupaten serta kota. Pembentukan TPK ini dimaksudkan untuk melakukan sosialisasi dan pelatihan sesuai dengan tingkatan masing-masing, sehingga daerah/satuan pendidikan terbantu dalam mengembangkan kurikulum sekolah. Pengalaman menunjukkan bahwa TPK dan satuan pendidikan dalam mengembangkan KTSP belum seperti yang diharapkan pada kurikulum berbasis kompetensi, khususnya dalam merancang proses pembelajaran dan penilaian mata pelajaran bahasa Inggris.

Kurikulum berbasis kompetensi menekankan penyelenggaraan proses pembelajaran yang berorientasi pada penguasaan kompetensi, sehingga guru didorong untuk menerapkan prinsip-prinsip pembelajaran tuntas dan penilaian autentik di mana penilaian terintegrasi dengan kegiatan pembelajaran dan tugas-tugas penilaian menggambarkan dunia nyata.

Pada dasarnya semua anak mampu belajar dan menguasai kompetensi yang ditargetkan, asalkan disesuaikan dengan karakteristik masingmasing anak dan kemampuan awal yang hilang dapat terdeteksi dengan benar sejak dini. Untuk itu perlu dilakukan penilaian sepanjang proses pembelajaran, sehingga apa yang menjadi kelemahan dan keberhasilan peserta didik dalam mempelajari suatu kompetensi dapat diketahui sejak awal. Dengan begitu, kelemahan anak bisa segera ditanggulangi dengan memberikan remedial dan anak yang berhasil diberi pengayaan.

Ada beberapa kriteria yang perlu digunakan ketika merancang alat penilaian proses atau formatif untuk mata pelajaran bahasa Inggris, sehingga mendapatkan hasil yang maksimal, yakni validitas isi, autentik, dan washback.

Dalam belajar bahasa, penilaian proses sangat penting, khususnya dalam mempelajari bahasa Inggris, karena itu sangat dianjurkan agar guru melaksanakan penilaian proses di samping penilaian hasil belajar. Penilaian sudah dilakukan ketika kegiatan pembelajaran berlangsung, sewaktu peserta didik belajar menggunakan bahasa target, misalnya untuk berdialog, bercerita, mencari informasi dari teks tertulis, dan mengungkapkan gagasan, perasaannya dan pendapatnya secara lisan maupun tertulis. Dengan demikian kompetensi yang belum dikuasai 
peserta didik dapat segera diketahui dan diberikan remedial.

Keterampilan berbahasa Inggris terdiri dari mendengarkan, berbicara, membaca, dan menulis. Dalam standar isi, standar kompetensi mata pelajaran bahasa Inggris dikelompokkan ke dalam empat keterampilan berbahasa tersebut. Namun dalam pelaksanaan pembelajaran, kegiatan berbahasa yang dirancang hendaknya melibatkan dua atau lebih keterampilan berbahasa, misalnya keterampilan mendengarkan dengan berbicara, keterampilan mendengarkan, menulis, dan berbicara. Dengan begitu ada keterpaduan pada keterampilan-keterampilan berbahasa tersebut seperti halnya kegiatan berkomunikasi pada dunia nyata.

Ketepatan cara penilaian yang dilakukan akan mempengaruhi Kegiatan pembelajaran, dan sumber belajar yang diterapkan guru dalam proses pembelajaran, di samping mempengaruhi kemampuan mengungkapkan hasil belajar peserta didik secara menyeluruh. Dalam melaksanakan penilaian perlu digarisbawahi bahwa tidak ada satupun alat peniaian yang dapat mengumpulkan informasi prestasi dan kemajuan belajar peserta didik secara lengkap. Penilaian tunggal tidak cukup untuk memberikan gambaran/informasi tentang kemampuan, keterampilan, pengetahuan, dan sikap peserta didik. Lagipula, interpretasi hasil penilaian tidak mutlak dan abadi karena anak terus berkembang sesuai dengan pengalaman belajar yang dialaminya.

\section{Saran}

Untuk melaksanakan penilaian mata pelajaran bahasa Inggris sesuai kurikulum berbasis kompetensi (KBK) beberapa saran berikut perlu dipertimbangkan. Pertama, bagi Pengguna kurikulum perlu memahami istilah-istilah linguistik yang digunakan pada standar isi Mata Pelajaran Bahasa Inggris, termasuk jenis-jenis teks (genre) yang masing-masing biasanya memiliki tujuan komunikatif, struktur teks, dan ciri-ciri linguistik tertentu. Kedua, dalam hal kompetensi komunikatif, adalah hasil kombinasi dari kompetensikompetensi linguistik, tindak tutur, sosiokultural dan strategis, serta piranti pembentuk wacana. Karena itu, penggunaan dari kompetensikompetensi pendukung tersebut juga perlu dicermati ketika guru menilai kompetensi peserta didik. Ketiga, untuk mengembangkan daya imajinasi dan kreativitas, peserta didik perlu dididik menjadi pembaca yang baik untuk menggunakan pengetahuan dan pengalamannya melakukan imaginative re-creation terhadap apa yang dibacanya. Imaginative re-creation mendorong peserta didik untuk menanggapi suatu karya secara personal dan individual serta memberi pengalaman belajar yang membantunya mempertajam tanggapannya dalam eksplorasi teks. Misalnya: mengubah sebuah episode dalam novel menjadi naskah drama, mengubah sebuah insiden dalam cerpen menjadi sebuah laporan untuk surat kabar. Keempat, untuk memudahkan pelaksanaan penilaian guru sudah menyiapkan dan membawa format pengamatan yang memuat nama-nama peserta didik serta aspek-aspek yang akan diamati ketika memasuki kelas.

\section{Pustaka Acuan}

Bachman, L.F. 1991. Fundamental Considerations in Language Testing. Oxford: Oxford University Press.

Brown, H.D. 2004. Teaching By Principles: An Interactive Approach To Language pedagogy. (2 nd ed.). New York: Longman. H.D. 2004. Language Assessment: principles and Classroom Practices. San Francisco: Longman.

Callaghan, M. dan Rothery, J. Teaching Factual Writing. 1988. Erskineville: Metropolitan East Disadvantaged Schools Program.

Celce-Murcia, M., Z. Dornyei, S. Thurrell. 1995. Communicative Competence: A Pedagogically Motivated Model with Content Specifications. In Issues in Applied Linguistics, 6/2, pp 5-35.

Departemen Pendidikan Nasional. 2004a. Kurikulum 2004 Bahasa Inggris SMP. Jakarta: Pusat Kurikulum, Balitbang Depdiknas. 
Departemen Pendidikan Nasional. 2004b. Pelayanan Profesional Kurikulum 2004 : Pedoman Penilaian Kelas . Jakarta: Pusat Kurikulum, Balitbang Depdiknas.

Gay,L.R. 1987. Competencies for Analysis and Application. Columbus: Merril Publishing Company.

Gronlund,N.E. 1982. Constructing Achievement Tests. New Jersey: Prentice Hall.

Kern Richard. 2000. Literacy and Language Teaching. Oxford : Oxford University Press.

Linn,R.L. dan Gronlund,N.E. 1995. Measurement and Assessment in Teaching $7^{\text {th }}$ edition. New Jersey: Prentice Hall.

MacNamara Tim. 1996. Measuring Second Language performance. New York: Longman.

Popham, W.J. 1995. Classroom Assessment, What Teachers Need to Know. Boston: Allyn \& Bacon.

Peraturan Menteri Pendidikan Nasional Republik Indonesia Nomor 22, Tahun 2006 tentang Standar Isi untuk Satuan Pendidikan Dasar dan Menengah. Jakarta: Departemen Pendidikan Nasional Republik Indonesia.

Peraturan Pemerintah Republik Indonesia Nomor 19, Tahun 2005 tentang Standar Nasional pendidikan. Departemen Pendidikan Nasional Republik Indonesia.

Surat Edaran Menteri Pendidikan Nasional Nomor 33, Tahun 2007 tentang Sosialisasi KTSP.

Undang-Undang Republik Indonesia Nomor 20, Tahun 2003 tentang Sistem Pendidikan Nasional. Jakarta: Departemen Pendidikan Nasional. 